\title{
Application of silver nanoparticles in food packages: a review
}

\author{
Emelda Orlando SIMBINE ${ }^{1,2}$, Larissa da Cunha RODRIGUES ${ }^{2}$, Judite LAPA-GUIMARÃES ${ }^{2}$, \\ Eliana Setsuko KAMIMURA², Carlos Humberto CORASSIN², Carlos Augusto Fernandes de OLIVEIRA ${ }^{2 *}$
}

\begin{abstract}
Silver nanoparticles (AgNPs) are antimicrobial agents that have a wide spectrum of action, including against pathogenic bacteria and spoilage fungi. However, their mechanism of action is not completely clarified. Nowadays, scientific interest on biological synthesis of AgNPs is growing, with emphasis in their extracellular biosynthesis by microbial cells, as it is the most reliable and ecologically correct method for production, yielding no toxic residues. AgNPs may be incorporated to biodegradable and non-biodegradable polymers for the production of food packages with antimicrobial properties, leading to greater safety and longer shelf life. However, it is important to carry out migration tests for new food packages incorporated with AgNPs, based on the effective levels for their inclusion in the packaging materials.
\end{abstract}

Keywords: silver nanoparticles; antimicrobial activity; food packaging; polymers.

Practical Application: One of the main objectives of the food industry is to increase the shelf life of foodstuffs by using appropriate methods of microbial control in processes and products. In this context, results listed in the present review on the application of silver nanoparticles (AgNPs) in food packages offer new perspectives to prevent microbial spoilage and increase shelf life. However, AgNPs should be produced by ecologically correct methods, and the results from different studies regarding their antimicrobial effects should be critically evaluated before using these materials in food packages.

\section{Introduction}

Microbial contamination of foods is one of the main problems of the food industry, considering the waste of spoiled products and the implications to public health due to foodborne diseases (Carbone et al., 2016). Therefore, food quality assurance systems applied to production processes are essential to generate products that are free of microbiological hazards. Additionally, post-processing technologies may contribute for the maintenance of food quality during shelf life. Antimicrobial effects may be reached by direct incorporation of biocidal agents in foods or in the space around them (Carbone et al., 2016). In this context, active packages with antimicrobial properties have been developed for different foods, especially packages with active biocidal substances, which may increase the quality of the product, its shelf life, and prevent spoilage caused by microbial action (Fernández et al., 2010; Gallocchio et al., 2016; Mahdi et al., 2012).

The first and most used materials in active packages were organic acids, enzymes, and polymers (biodegradable and non-degradable). Recently, nanoparticles (NPs) of metals or metallic oxides have been introduced with greater advantages compared with organic and inorganic acids, as they are resistant to the most severe processing conditions (Carbone et al., 2016), such as exposure to high temperatures (Emamifar et al., 2012). Nanotechnology is a promising interdisciplinary science in which new materials are developed in nanoscale, with applications in the fields of medicine, electricity, mechanics, catalysis, photonics, molecular computing, among others (Chen et al., 2016; Kanmani
\& Lim, 2013). The introduction of nanotechnology in the food packaging industry may offer potential solutions for the challenge presented by short shelf life products, improving their quality and keeping them free of microbial adhesion (Emamifar et al., 2012; Qian et al., 2013). Metallic nanoparticles based on magnesium oxide, copper oxide, zinc oxide, cadmium selenite/tellurite, and titanium, silver and gold dioxide, have been studied because of their antimicrobial activity (AbdelRahim et al., 2017; Almeida et al., 2015; Echegoyen \& Nerín, 2013; Silvestre et al., 2011).

Metallic NPs may be obtained by physical, chemical or biological methods, and antimicrobial activity varies according with the method of synthesis (Durán et al., 2010). Nowadays, research on biological synthesis of NPs has increased markedly, with emphasis in the microbial production of these compounds, as it is considered the most reliable and ecologically correct method (Wei et al., 2012). Among metallic nanoparticles, silver nanoparticles (AgNPs) have been widely studied due to their peculiar properties and their extensive application in the production of biomaterials (AbdelRahim et al., 2017), and in the food, cosmetics, clothing, and pharmaceutical industries (Chen et al., 2016; Kanmani \& Lim, 2013). Additionally, when compared with other metals, silver presents the lowest toxicity for animal cells (Berni et al., 2008). Therefore, the most recent studies on antimicrobial nanocompounds in food packages are based on AgNPs (Emamifar et al., 2012; Gallocchio et al., 2016; Martinez-Abad et al., 2012). Although AgNPs are listed by the

${ }^{1}$ Departamento de Para-Clínicas: Secção de Higiene e Tecnologia de Alimentos, Faculdade de Veterinária, Universidade Eduardo Mondlane, Maputo, Moçambique

${ }^{2}$ Departamento de Engenharia de Alimentos, Faculdade de Zootecnia e Engenharia de Alimentos, Universidade de São Paulo - USP, Pirassununga, SP, Brasil

*Corresponding author: carlosaf@usp.br 
U.S. Food and Drug Administration as generally recognized as safe (GRAS) materials (Emamifar et al., 2012), there is a concern about the potential health effects associated with high intake levels caused by migration of these particles from the packaging to the foods (Claro \& Magalhães, 2017; Echegoyen \& Nerín, 2013; Gallocchio et al., 2016). Thus, the objective of this paper is to review the available data published in the past 5 years on the mechanisms of action, microbial synthesis, toxicological aspects and antimicrobial properties of AgNPs, as well as their potential applications in the food industry.

\section{Mechanisms of action of silver nanoparticles}

According to Kanmani \& Lim (2013), AgNPs have a wide spectrum of antimicrobial activity, including Gram-positive and negative bacteria, fungi, and viruses. It is known that AgNPs are toxic to a large variety of microorganisms (Morones et al., 2005) including Escherichia coli, Enterococcus faecalis, Staphylococcus aureus, S. epidermidis, Vibrio cholerae, Pseudomonas aeruginosa, Shigella flexneri, Bacillus anthracis, B. subtilis, B. cereus, Proteus mirabilis, Salmonella enterica typhimurium, Micrococcus luteus, Listeria monocytogenes, and Klebsiella pneumoniae (Almeida et al., 2015). The bactericidal effect of AgNPs was first quantified by Von Naegelis, using silver ions against algae (Berni et al., 2008). However, it is not clear if AgNPs present a specific mechanism of action (Morones et al., 2005), or if their antimicrobial activity is only associated with the release of $\mathrm{Ag}+$ ions, their bioactive form (Almeida et al., 2015; Sobye et al., 2015). On the other hand, Sobye et al. (2015) proposed different mechanisms by which AgNPs inhibit or reduce the growth and metabolism of bacterial cells, leading to accelerated lysis.

The antimicrobial effect of silver, silver ions, and silver nanoparticles has been studied, aiming to evaluate the mechanism of action against a wide range of bacteria (Pal et al., 2007). Morones et al. (2005) evaluated the bactericidal effect of AgNPs, and identified three main mechanisms of action of the nanoparticles: (1) AgNPs in the range of 1 to $10 \mathrm{~nm}$ bound to the surface of the cell membrane and drastically interfere with its functions, such as permeability and respiration; (2) AgNPs are able to penetrate the bacterial cells and damage them, possibly by interacting with compounds containing sulfur and phosphorus, such as DNA; (3) AgNPs release silver ions, which are potentially very reactive and may react with the negatively charged cell membrane, providing an additional contribution to the bactericidal effect of silver nanoparticles.

A study carried out by Sobye et al. (2015) demonstrated that, under anaerobiosis conditions, AgNPs do not show bactericidal effect, even at high concentrations. The authors supported the hypothesis that silver ions are not released in the absence of oxygen. Pal et al. (2007) observed different inhibition effects of AgNPs on E. coli, which activities varied according to the size and shape of particles. However, little is known about the change in AgNPs biological activity caused by the shape of the particle. According to Sobye et al. (2015), AgNPs may have different shapes, but the most interesting particles in terms of antimicrobial effect are spherical and triangular, with greater antimicrobial effect of triangular particles than spherical possibly because of their larger contact surface.

\section{Biosynthesis of silver nanoparticles and antimicrobial activity}

The biological synthesis of AgNPs (involving bacteria, fungi, and biomolecules) has been widely researched, since it is considered as a reliable and ecologically correct method (Durán et al., 2010; Wei et al., 2012). Additionally, biological synthesis does not yield any toxic residues (Husseiny et al., 2015). Durán et al. (2010) reported that plant extracts may also be used in metallic nanoparticle production. Microbial synthesis of metallic NPs may be intracellular (Das et al., 2014) or extracellular (AbdelRahim et al., 2017; Das et al., 2014; Gopinath \& Velusamy, 2013; Prakasham et al., 2014), yielding NPs of different sizes, shapes and antimicrobial efficacy (Husseiny et al., 2015).

Several studies have focused on extracellular synthesis of metallic nanoparticles because of its relative simplicity and lower cost compared with intracellular synthesis (Das et al., 2014). The mechanisms involved in the extracellular synthesis of nanoparticles using microorganisms have not been completely clarified. However, Das et al. (2014) postulated that the synthesis is related to the presence of nitrate reductase enzymes released by the microorganisms, which are responsible for the bio-reduction of metallic ions and metallic nanoparticles. This phenomenon may be evidenced by the color change using spectrophotometry (Elbeshehy et al., 2015). Taking into account the accessibility and easy genetic modification, bacteria are the most promising candidates to AgNPs synthesis (Wei et al., 2012; Elbeshehy et al., 2015; Kanmani \& Lim, 2013; Singh et al., 2013b).

\subsection{Biosynthesis of AgNPs by bacterial species}

The main genera of bacteria that exhibit effective synthesis of AgNPs include Bacillus spp. (Das et al., 2014; Elbeshehy et al., 2015; Gopinath \& Velusamy, 2013; Wei et al., 2012), Streptomyces spp. (Manikprabhu \& Lingappa, 2013; Mohanta \& Behera, 2014; Prakasham et al., 2014) Acinetobacter spp. (Singh et al., 2013b), and Pseudomonas spp. (Gopinath et al., 2017; Peiris et al., 2017). Bacterial strains used for AgNPs synthesis were mainly isolated in samples of soil sediment contaminated by heavy metals (Das et al., 2014; Elbeshehy et al., 2015; Mohanta \& Behera, 2014), and marine sediments (Manivasagan et al., 2013; Prakasham et al., 2014). Table 1 presents the outcomes from recent studies on the bacterial biosynthesis of AgNPs, size and shape of AgNPs produced, as well as the microbial species tested for their minimum inhibitory concentration.

Kanmani \& Lim (2013) synthesized bacterial AgNPs by direct reduction of silver nitrite by the exopolysaccharide, and demonstrated their antibacterial and antifungal activity with different susceptibilities of bacterial species in the following order: $P$. aeruginosa $>$ E.coli and K. pneumonia $>$ L. monocytogenes. The inhibition zone observed for bacterial species was achieved at $2 \mathrm{mg} / \mathrm{mL}$ AgNPs, while fungal zone of inhibition ranged between 0.2 to $2 \mathrm{mg} / \mathrm{mL}$, with greater susceptibility of Aspergillus spp. than Penicillium spp. AgNPs derived from Acinetobacter spp. biosynthesis using an extract of free cells of the microorganism had antimicrobial activity against Gram-positive and negative bacteria (Singh et al., 2013b). Wei et al. (2012) produced bacterial 
Table 1. Antimicrobial effect of silver nanoparticles synthesized by bacterial strains.

\begin{tabular}{|c|c|c|c|c|c|}
\hline Producer species & $\begin{array}{l}\text { Particle size } \\
\quad(\mathrm{nm})\end{array}$ & $\begin{array}{l}\text { Particle } \\
\text { shape }\end{array}$ & Microbial species tested & $\begin{array}{c}\mathrm{MIC} \\
(\mathrm{mg} / \mathrm{mL})\end{array}$ & Reference \\
\hline $\begin{array}{l}\text { Acinetobacter } \\
\text { calcoaceticus LRVP54 }\end{array}$ & $8-12$ & NI & $\begin{array}{l}\text { P. aeruginosa and } A . \text { Baumannii } \\
\text { S. aureus and } S \text {. mutans }\end{array}$ & $\begin{array}{l}150-600 \\
>1.000\end{array}$ & Singh et al. (2013a) \\
\hline Acid lactic bacteria & $2-15$ & $\begin{array}{l}\text { Spherical } \\
\text { Triangular }\end{array}$ & $\begin{array}{l}\text { P. aeruginosa, E. coli, Klebsiela pneumonia and } L . \\
\text { monocytogenes } \\
\text { Aspergillus spp. and Penicillium spp }\end{array}$ & $0.2-2$ & $\begin{array}{l}\text { Kanmani \& Lim } \\
\text { (2013) }\end{array}$ \\
\hline Bacillus spp. GP-23 & $7-21$ & Spherical & F. oxysporum & 0.08 & $\begin{array}{l}\text { Gopinath \& } \\
\text { Velusamy (2013) }\end{array}$ \\
\hline $\begin{array}{l}\text { Stenotrophomonas } \\
\text { maltophilia } \\
\text { (GenBank: JN247637.1) }\end{array}$ & 93 & Cubic & S. aureus, E. coli and S. marcescens & $0.0125-0.05$ & Oves et al. (2013) \\
\hline $\begin{array}{l}\text { Nocardiopsis spp. } \\
\text { MBRC-1 }\end{array}$ & $30-90$ & Spherical & $\begin{array}{l}\text { B. subtilis ATCC } 6633 \\
\text { P. aeruginosa ATCC } 27853 \text { and C. albicans ATCC } 10231 \\
\text { E. coli ATCC } 1053613 \text { and A. fumigatus ATCC } 1022 \\
\text { S. aureus ATCC } 6538 \\
\text { E. hirae ATCC } 10541 \text { and A. niger ATCC } 1015 \\
\text { S. flexneri ATCC } 12022 \text { and A. brasiliensis } \\
\text { ATCC } 16404\end{array}$ & $\begin{array}{l}0.007 \\
0.01 \\
0.013 \\
0.014 \\
0.016 \\
0.018\end{array}$ & $\begin{array}{l}\text { Manivasagan et al. } \\
(2013)\end{array}$ \\
\hline Streptomyces coelicolor & $28-50$ & Irregular & methicillin-resistant S. aureus & 0.03 & $\begin{array}{l}\text { Manikprabhu \& } \\
\text { Lingappa (2013) }\end{array}$ \\
\hline $\begin{array}{l}\text { Streptomyces parvulus } \\
\text { SSNP11 }\end{array}$ & $1.7-11.7$ & Spherical & P. putida, S. typhi, B. subtilis and K. pnuemoniae & NI & $\begin{array}{l}\text { Prakasham et al. } \\
\text { (2014) }\end{array}$ \\
\hline Streptomyces spp. SS2 & $67.9 \pm 18.5$ & Spherical & $\begin{array}{l}\text { E. coli (MTCC 1089), B. subtilis (MTCC 7164), S. } \\
\text { epidermitis (MTCC 3615), V. cholerae (MTCC 3904), } \\
\text { and S. aureus (MTCC 1144) }\end{array}$ & NI & $\begin{array}{l}\text { Mohanta \& Behera } \\
(2014)\end{array}$ \\
\hline $\begin{array}{l}\text { Bacillus licheniformis } \\
\text { (NPs-3) }\end{array}$ & $77-92$ & $\begin{array}{l}\text { Triangular, } \\
\text { hexagonal } \\
\text { and } \\
\text { spherical }\end{array}$ & $\begin{array}{l}\text { E. coli, S. sonnei and } K \text {. pneumonia } \\
\text { P. aeruginosa } \\
\text { S. aureus } \\
\text { S. bovis }\end{array}$ & $\begin{array}{l}0.0032 \\
0.0063 \\
0.0125 \\
0.025\end{array}$ & $\begin{array}{l}\text { Elbeshehy et al. } \\
\text { (2015) }\end{array}$ \\
\hline $\begin{array}{l}\text { Pseudomonas aeruginosa } \\
\text { ATCC } 27853\end{array}$ & $33-300$ & Spherical & $\begin{array}{l}\text { E. coli, S. aureus, } \text { P. aeruginosa, S. aureus, } S \text {. } \\
\text { typhimurium, Acinetobacter and C. albicans }\end{array}$ & NI & Peiris et al. (2017) \\
\hline $\begin{array}{l}\text { Streptacidiphilus } \\
\text { durhamensis }\end{array}$ & $100-700$ & Spherical & $\begin{array}{l}\text { S. aureus ATCC } 6338, \text { B. subtilis PCM2021, E. coli } \\
\text { ATCC } 8739, \text { K. pneumoniae ATCC } 700603 \text { and S. infantis } \\
\text { P. mirabilis } \\
\text { P. aeruginosa ATCC } 10145\end{array}$ & $\begin{array}{l}0.00625 \\
0.05 \\
0.025\end{array}$ & $\begin{array}{l}\text { Buszewski et al. } \\
\text { (2018) }\end{array}$ \\
\hline Bacillus spp. SBT8 & $1-20$ & $\begin{array}{l}\text { Spherical } \\
\text { and } \\
\text { pseudo- } \\
\text { spherical }\end{array}$ & $\begin{array}{l}\text { L. monocytogenes } \\
\text { S. aureus } \\
\text { E. coli } \mathrm{O} 157: \mathrm{H} 7 \\
\text { S. typhimurium } \\
\text { P. aeruginosa }\end{array}$ & $\begin{array}{l}0.4 \\
0.1 \\
0.6 \\
0.4 \\
0.6\end{array}$ & Yurtluk et al. (2018) \\
\hline $\begin{array}{l}\text { Pseudomonas spp. } \\
\text { THG-LS1.4 }\end{array}$ & $10-40$ & Irregular & $\begin{array}{l}\text { B. cereus, S. aureus, C. tropicalis, V. parahaemolyticus, E. } \\
\text { coli, P. aeruginosa and S. enterica }\end{array}$ & NI & Singh et al. (2018) \\
\hline $\begin{array}{l}\text { Streptomyces } \\
\text { xinghaiensis OF1 }\end{array}$ & $5-20$ & $\begin{array}{l}\text { Spherical } \\
\text { and polydis } \\
\text { persed }\end{array}$ & $\begin{array}{l}\text { P. aeruginosa ATCC } 10145 \\
\text { E. coli ATCC } 8739 \\
\text { B. subtilis PCM } 2021 \\
\text { K. pneumoniae ATCC } 700603 \\
\text { S. aureus ATCC } 6538 \\
\text { C. albicans ATCC } 10231 \\
\text { M. furfur DSM } 6170\end{array}$ & $\begin{array}{l}0.016 \\
0.064 \\
0.256 \\
0.032 \\
0.032 \\
0.032 \\
0.032\end{array}$ & Wypij et al. (2018) \\
\hline B. brevis (NCIM 2533) & $22-60$ & Spherical & S. aureus and S. typhi using & NI & $\begin{array}{l}\text { Saravanan et al. } \\
(2018)\end{array}$ \\
\hline E. coli & 33.6 & Spherical & E. coli, $P$. aeruginosa, K. pneumoniae and S. aureus & NI & $\begin{array}{l}\text { Neihaya \& Zaman } \\
\text { (2018) }\end{array}$ \\
\hline $\begin{array}{l}\text { Pseudomonas aeruginosa } \\
\text { ATCC } 27853\end{array}$ & $33-300$ & Spherical & $\begin{array}{l}\text { E. coli, S. aureus, } \text { P. aeruginosa, S. aureus, } S . \\
\text { typhimurium, Acinetobacter and C. albicans }\end{array}$ & $\mathrm{NI}$ & Peiris et al. (2017) \\
\hline $\begin{array}{l}\text { Bacillus licheniformis } \\
\text { (NPs-3) }\end{array}$ & $77-92$ & $\begin{array}{l}\text { Triangular, } \\
\text { hexagonal } \\
\text { and } \\
\text { spherical }\end{array}$ & $\begin{array}{l}\text { E. coli, S. sonnei and } K \text {. pneumonia } \\
\text { P. aeruginosa } \\
\text { S. aureus } \\
\text { S. bovis }\end{array}$ & $\begin{array}{l}0.0032 \\
0.0063 \\
0.0125 \\
0.025\end{array}$ & $\begin{array}{l}\text { Elbeshehy et al. } \\
\text { (2015) }\end{array}$ \\
\hline
\end{tabular}

MIC: Minimum inhibitory concentration; NI: Not informed. 
AgNPs from Bacillus amyloliquefaciens by solar irradiation, and these nanoparticles presented antimicrobial effects, with B. subtilis being more susceptible $(0.009 \mathrm{mg} / \mathrm{mL})$ than $E$. coli. Gopinath \& Velusamy (2013) synthetized AgNPs using Bacillus spp. GP-23, and observed effective antifungal activity against Fusarium oxysporum at $0.008 \mathrm{mg} / \mathrm{mL}$.

Bacillus spp. strains isolated from soil samples contaminated with heavy metals were highly efficient for intracellular and extracellular synthesis of AgNPs (spherical, 42-92 nm) (Das et al., 2014). Elbeshehy et al. (2015) identified new strains of Bacillus (B. pumilus, B. persicus, and B. licheniformis) that were efficient in the AgNPs extracellular synthesis. AgNPs produced by $B$. licheniformis presented strong antibacterial effect against Gram-negative bacteria (E. coli, K. pneumoniae, S. sonnei, P. aeruginosa), followed by Gram-positive ones (S. epidermidis, S. aureus - methicillin- resistant strain - and S. bovis). Significant antifungal effects were also observed against $A$. flavus and C. albicans ATCC 1021.

AgNPs produced by Streptomyces albidoflavus were evaluated by Prakasham et al. (2012) by determining the inhibition zones against bacterial species. The author observed high antibacterial effects against $K$. pneumonia $(36 \mathrm{~mm})$, followed by $M$. luteus $(28 \mathrm{~mm})$, and B. subtilis $(24 \mathrm{~mm})$, and lower effect against E. coli $(22 \mathrm{~mm})$. On the other hand, Mohanta \& Behera (2014) developed the extracellular biosynthesis of AgNPs using Streptomyces sp. SS2 isolated from soil sediment samples, and demonstrated potential antimicrobial activity of AgNPs against E. coli, B. subtilis, S. epidermis, V. cholerae, and S. aureus. The largest and the smallest zone of inhibition were observed against $V$. cholerae and B. subtilis, respectively.

Prakasham et al. (2014) characterized AgNPs obtained from extracellular synthesis by strains of actinomycetes (Streptomyces parvulus SSNP11) isolated from samples of marine sediment. The AgNPs had effective antibacterial activity against Gram-negative and positive bacteria, including P. putida, K. pneumoniae, B. subtilis, and S. typhi. Manivasagan et al. (2013) studied the biosynthesis of AgNPs (spherical, average size $45 \pm 0.15 \mathrm{~nm}$ ) by Nocardiopsis sp. MBRC-1 isolated from samples of marine sediment. The resulting particles had significant antimicrobial effects against several microorganisms including bacteria (E. coli, B. subtilis, E. hirae, P. aeruginosa, S. flexneri, and S. aureus) and fungi (A. niger, A. brasiliensis, A. fumigates, and C. albicans).

Peiris et al. (2017) produced AgNPs using Pseudomonas aeruginosa ATCC 27853, and demonstrated that the nanoparticles were effective against Gram-negative and positive bacteria (E. coli ATCC 25922, S. aureus ATCC 25923, P. aeruginosa ATCC 27853, S. typhimurium, Acinetobacter) as well as fungi (C. albicans). Gopinath et al. (2017) obtained AgNPs by biogenic extracellular synthesis using the bacterium P. putida MVP2. The AgNPs were efficient against Gram-positive and negative bacteria, including S. aureus, E. coli, B. cereus, P. aeruginosa, and H. pylori. AgNPs produced by biosynthesis using the acidophilic actinobacterium Streptacidiphilus durhamensis HGG16n had high antimicrobial effect against $P$. aeruginosa, $S$. aureus, and $P$. mirabilis, followed by E. coli, K. pneumoniae, and B. subtilis (Buszewski et al., 2018).
In summary, low levels of AgNPs synthesized by bacterial species presented strong antimicrobial activity effect against $S$. aureus, $P$. aeruginosa, B. subtilis, E. coli, although higher concentrations were required to become effective against other important pathogenic microorganisms including L. monocytogenes and S. typhimurium.

\subsection{Biosynthesis of AgNPs by fungi species}

There are several reports demonstrating the biosynthesis of AgNPs by fungi species, mostly of them related to the use of endophytic fungi (those isolated from parts of plants) (Devi \& Joshi, 2015; Qian et al., 2013; Singh et al., 2017; Sogra Fathima \& Balakrishnan, 2014). The main genera of fungi reported as efficient in extracellular biosynthesis of AgNPs include Fusarium spp. (Balakumaran et al., 2015; Husseiny et al., 2015; Sogra Fathima \& Balakrishnan, 2014), Aspergillus (Balakumaran et al., 2015; Devi \& Joshi, 2015; Ninganagouda et al., 2013), and Penicllium (Balakumaran et al., 2015; Devi \& Joshi, 2015; Ma et al., 2017; Singh et al., 2013a). AgNPs produced by fungal biosynthesis have antimicrobial properties against a wide range of pathogenic microorganisms, including fungi, Gram-positive and negative bacteria, as shown in Table 2 .

Gade et al. (2013) studied the ability of 18 species in the genus Phoma spp. to produce AgNPs, and concluded that all of them were efficient in terms of AgNPs biosynthesis. In general, the process yielded spherical nanoparticles, except for the species P. sorghina MTCC-2096, which produced AgNPs in the shape of nanorods. Sogra Fathima \& Balakrishnan (2014) studied the extracellular biosynthesis and optimization of AgNPs, using the endophytic fungus Fusarium solani. These authors obtained AgNPs of different shapes, with the predominance of $10-\mathrm{nm}$, spherical AgNPs. Husseiny et al. (2015) demonstrated that the AgNPs (spherical and uniformly distributed) synthesized by Fusarium oxysporum were effective against $S$. aureus and E. coli. Ninganagouda et al. (2013) reported AgNPs extracellular biosynthesis by Aspergillus flavus, which were efficient against the Gram-negative bacteria tested, P. aeruginosa, E. coli and K. pneumonia.

Regarding the antifungal properties of AgNPs from fungal biosynthesis, Qian et al. (2013) observed a high extracellular biosynthesis of AgNPs by the endophytic fungus Epicoccum nigrum isolated from Phellodendron amurense. The antifungal activities of the AgNPs obtained were demonstrated against 9 fungus strains (Candida albicans ATCC 90028, C. parapsilosis ATCC 22019, C. tropicalis JLCC 31384, C.krusei ATCC 6258, Cryptococcus neoformans IFM 45687, A. fumigatus IFM 40808, A.flavus IFM 55648, F. Solani JLCC 30866, and Sporothrix schenckii JLCC 32757). Studies demonstrated that endophytic fungi (Aspergillus tamarii PFL2, Aspergillus niger PFR6 and Penicllium ochrochloron PFR8) isolated from the ethno medicinal plant Potentilla fulgens L. also show the ability to synthetize AgNPs (Devi \& Joshi, 2014, 2015). Cryptosporiopsis ericae PS4 was also efficient for extracellular biosynthesis of AgNPs, which were effective against pathogenic microorganisms, including S. aureus MTCC96, S. enteric MTCC735, E. coli MTCC730, E. faecalis MTCC2729, and C. albicans MTCC 183 (Devi \& Joshi, 2014). Chen et al. (2016) produced AgNPs using an exopolysaccharide obtained 
Simbine et al.

Table 2. Antimicrobial effect of silver nanoparticles synthesized by fungus strains.

\begin{tabular}{|c|c|c|c|c|c|}
\hline Producer species & $\begin{array}{c}\text { Particle } \\
\text { size }(\mathrm{nm})\end{array}$ & Particle shape & Microbial species tested & $\begin{array}{c}\mathrm{MIC} \\
(\mathrm{mg} / \mathrm{mL})\end{array}$ & Reference \\
\hline Aspergillus flavus & NI & NI & P. aeruginosa, E. coli and K. pneumonia & 0.02 & Ninganagouda et al. (2013) \\
\hline \multirow[t]{3}{*}{ Epicoccum nigrum } & $1-22$ & Spherical & C. tropocalis, F. solani and A. fumigatus & 0.001 & Qian et al. (2013) \\
\hline & & & A. flavus and C. albicans & 0.0005 & \\
\hline & & & C. parapsilosis and C. krusei & 0.0000125 & \\
\hline \multirow{2}{*}{ Cryptosporiopsis ericae PS4 } & & & $\begin{array}{l}\text { S. aureus MTCC } 96 \text { and E. faecalis } \\
\text { MTCC } 2729\end{array}$ & 0.002 & \\
\hline & & & C. albicans MTCC183 & 0.0001 & \\
\hline Aspergillus tamarii & $3.5 \pm 3.3$ & Spherical & NI & NI & Devi \& Joshi (2015) \\
\hline Aspergillus niger & $8.7 \pm 6$ & & & & \\
\hline \multirow{2}{*}{ Guignardia spp. } & & & E. coli, S. epidermidis and B. subtilis & 0.00625 & \\
\hline & & & E. faecalis & 0.000125 & \\
\hline Cs-HK1 fungus (not specified) & $30-40$ & - & E. coli & 1.6 & Chen et al. (2016) \\
\hline Penicillium aculeatum Su1 & $4-55$ & Spherical & $\begin{array}{l}\text { E. coli ATCC-8739, } P \text {. aeruginosa, } \\
\text { ATCC-15442, S. aureus ATCC, B. subtilis, } \\
\text { ATCC- } 663 \text {, C. albicans ATCC- } 10231\end{array}$ & $0.05-0.2$ & Ma et al. (2017) \\
\hline Alternaria spp. & $10-30$ & Spherical & $\begin{array}{l}\text { methicillin-resistant B. subtilis, S. aureus, } \\
\text { E. coli and S. marcescens }\end{array}$ & $\mathrm{NI}$ & Singh et al. (2017) \\
\hline Fusarium oxysporum & $34-44$ & NI & E. coli & 11.1 & Hamedi et al. (2017) \\
\hline $\begin{array}{l}\text { Ganoderma enigmaticum and } \\
\text { Trametes ljubarskyi }\end{array}$ & 15 & Spherical & $\begin{array}{l}\text { B. subtilis MTCC 441, S. aureus MTCC } \\
96, \text { M. luteus KUCCC 4, Staphylococcus } \\
\text { KUCC 7, E. coli MTCC 443, P. putida } \\
\text { KUCCC 12, K. pneumoniae MTCC } 109 \\
\text { and K. aerogenes MTCC } 98\end{array}$ & NI & Gudikandula et al. (2017) \\
\hline $\begin{array}{l}\text { Phenerochaete chrysosporium } \\
\text { (MTCC- 787) }\end{array}$ & $34-90$ & $\begin{array}{l}\text { Spherical and } \\
\text { oval }\end{array}$ & $\begin{array}{l}\text { P. aeruginosa, K. pneumoniae, S. aureus } \\
\text { and S. epidermidis }\end{array}$ & NI & Saravanan et al. (2018) \\
\hline Fusarium oxysporum & $1-50$ & Spherical & E. coli and $P$. aeruginosa & 0.01 & Srivastava et al. (2019) \\
\hline
\end{tabular}

MIC: Minimum inhibitory concentration; NI: Not informed.

by means of fermentation of a medicinal fungus and $\mathrm{AgNO}_{3}$ in distilled water. These nanoparticles showed antimicrobial effect against Gram-positive and negative bacteria.

The aqueous extract of the mycelium of Rhizopus stolonifer demonstrated to be effective in the biosynthesis of spherical) AgNPs (diameter: $9.46 \pm 2.64 \mathrm{~nm}$ ) (AbdelRahim et al., 2017). The AgNPs produced by the fungus Cordyceps sinensis (Berk.) Sacc Cs-HK1, presented antimicrobial activity against E. coli $(1.6 \mathrm{mg} / \mathrm{mL})$ and $S$. aureus $(0.8 \mathrm{mg} / \mathrm{mL})$ (Chen et al., 2016). Singh et al. (2017) reported the extracellular biosynthesis of spherical AgNPs (diameter: $4-30 \mathrm{~nm}$ ) using the supernatant of an endophytic fungus (Alternaria spp) isolated from Raphanus sativus, which showed antimicrobial properties against pathogenic bacteria (methicillin-resistant B. subtilis, S. aureus, E. coli and
S. marcescens). The endophytic fungus Pencillium spp. isolated from the leaves of Curcuma longa was efficient in the extracellular biosynthesis of spherical AgNPs (diameter: $25 \mathrm{~nm}$ ), which was effective against several pathogens, especially $P$. aeruginosa and K. pneumoniae (Singh et al., 2013a).

Balakumaran et al. (2015) isolated 13 species of endophytic fungi in 9 different samples of plant leaves, and observed that only 6 fungi (A. niger, Aspergillus spp., Colletotrichum spp., F. oxysporum, Guignardia spp., and Penicillium spp.) were able to produce AgNPs by extracellular biosynthesis. In particular, Guignardia spp., isolated from Citrus spp., showed the best results for extracellular biosynthesis of AgNPs that were effective against several Gram-negative and Gram-positive bacterial species, including E. coli ATCC 8739, Proteus mirabilis MTCC 425, 
P. aeruginosa ATCC 27853, S. aureus ATCC 29736, E. faecalis ATCC 29212 and B. subtilis ATCC 6633. AgNPs produced by the fungus Penicillium aculeatum Sul also presented antimicrobial activity against Gram-negative and positive bacteria and fungi at levels of $0.05-0.2 \mathrm{mg} / \mathrm{mL}$, with greatest effect on C. albicans, followed by $P$. aeruginosa, B. subtilis, S. aureus and E. coli (Ma et al., 2017).

\section{Application of silver nanoparticles in food packaging}

Many of the packages used in the food industry are made of petroleum-based plastics. When compared with other materials (paper, glass, wood, metals and ceramic), plastic packages have advantages in terms of physical-mechanic characteristics, such as weight, flexibility, mechanical resistance, and physical-chemical and biological characteristics related to quality, health protection and safety (Claro \& Magalhães, 2017). These features provide to plastic materials excellent conditions to produce active packages obtained by the addition of nanocompounds with antimicrobial properties. According to Almeida et al. (2015), packages with nanotechnological applications have better physical-chemical properties, reduced hydrophilic characteristics, better biodegradability, and increased value-added. Active packages make up a new generation of food packages obtained by the incorporation of metallic nanoparticles to polymer films (Emamifar et al., 2012).

The advantage of silver antimicrobial agents is that they can be easily incorporated to several materials, such as plastics and textiles, making them useful in wide spectrum applications, maintaining their antimicrobial activity in situ, in which traditional antimicrobial agents would be unstable (Almeida et al., 2015). According to Carbone et al. (2016), AgNPs may be incorporated to non-degradable (polyethylene, polyvinyl chloride, vinyl alcohol) and biodegradable polymers (cellulose, starch, chitosan, agarose) to produce food packages, as presented in Table 3.

Emamifar et al. (2012) evaluated the inhibition effect of packages impregnated with $\mathrm{Ag}$ and $\mathrm{ZnO}$ nanoparticles on Lactobacillus plantarum in orange juice, and observed that the bacterium was inhibited in the product stored at $4{ }^{\circ} \mathrm{C}$. However, the silver nanoparticle presented the greatest antimicrobial activity, compared with the $\mathrm{ZnO}$ nanoparticle, in juices stored for up to 112 days. Panea et al. (2014) demonstrated the antimicrobial

Table 3. Antimicrobial effect of silver nanoparticles (AgNP) incorporated to food packages.

\begin{tabular}{|c|c|c|c|c|c|}
\hline AgNP characteristics & Package & Food product & Storage conditions & Antimicrobial effect & Reference \\
\hline Spherical $(40-50 \mathrm{~nm})$ & PVC & Minced beef & $3 \pm 1{ }^{\circ} \mathrm{C}$ for 14 days & $\begin{array}{l}\text { Inhibitory effect on microbial } \\
\text { growth after } 7 \text { days for } \\
\text { mesophilic, total bacteria and } \\
\text { S. aureus, and after } 10 \text { days } \\
\text { for E. coli }\end{array}$ & Mahdi et al. (2012) \\
\hline Zinc oxide + AgNP & LDPE & Chicken breast cooked & $4^{\circ} \mathrm{C}$ for 21 days & $\begin{array}{l}\text { Inhibitory effect on } \\
\text { Enterobacteriaceae and } \\
\text { mesophilic bacteria }\end{array}$ & Panea et al. (2014) \\
\hline $\begin{array}{l}\text { Pullulan }+ \\
\text { spherical }(40-100 \mathrm{~nm})\end{array}$ & NI & $\begin{array}{l}\text { Raw turkey breast, raw } \\
\text { beef, and ready-to-eat } \\
\text { turkey breast }\end{array}$ & $4^{\circ} \mathrm{C}$ for 21 days & $\begin{array}{l}\text { Effectiveness against } S \text {. } \\
\text { aureus, L. monocytogenes, } \\
\text { E. coli } \mathrm{O} 157: \mathrm{H} 7\end{array}$ & Morsy et al. (2014) \\
\hline Spherical (3-20 nm) & LDPE & Fresh pork sirloin & $6^{\circ} \mathrm{C}$ for 28 days & $\begin{array}{l}\text { Decrease in viable counts of } \\
\text { L. piscium, B. thermosphacta, } \\
\text { H. alvei, L. sakei and } \\
\text { C. divergens }\end{array}$ & Kuuliala et al. (2015) \\
\hline $\begin{array}{l}\text { Spherical } \\
(10.10+0.60 \mathrm{~nm})\end{array}$ & LDPE & Chicken breast fillet & $4^{\circ} \mathrm{C}$ for 12 days & $\begin{array}{l}\text { Changes in viable counts } \\
\text { of psychrotrophic bacteria, } \\
\text { Pseudomonas spp., lactic acid } \\
\text { bacteria, B. thermosphacta, } \\
\text { E. coli, and total coliforms }\end{array}$ & $\begin{array}{l}\text { Azlin-Hasim et al. } \\
(2015)\end{array}$ \\
\hline NI & Plastic & Fresh chicken meatballs & $5 \pm 1^{\circ} \mathrm{C}$ for 7 days & $\begin{array}{l}\text { Effectiveness against } \\
\text { Enterobacteriaceae and } \\
\text { Pseudomonas spp. }\end{array}$ & Gallocchio et al (2016) \\
\hline $\begin{array}{l}\text { Spherical }(35 \mathrm{~nm}) \\
+\mathrm{CuO}(50 \mathrm{~nm})+ \\
\mathrm{ZnO}(50-30 \mathrm{~nm})\end{array}$ & LDPE & Ultra-filtrated cheese & $4 \pm 0.5^{\circ} \mathrm{C}$ for 28 days & $\begin{array}{l}\text { Decrease in the most } \\
\text { probable number of coliforms }\end{array}$ & $\begin{array}{l}\text { Beigmohammadi et al. } \\
\text { (2016) }\end{array}$ \\
\hline AgNPs & PVC & $\begin{array}{l}\text { Walnut, hazelnut, } \\
\text { pistachio almond }\end{array}$ & $\begin{array}{l}\text { Room temperature, } \\
24 \text { months }\end{array}$ & $\begin{array}{l}\text { Decrease total bacteria count } \\
\text { and coliform }\end{array}$ & Tavakoli et al. (2017) \\
\hline $\mathrm{TiO}_{2}+\mathrm{Ag}(10 \mathrm{~nm})$ & PLA & Yunnan cottage cheese & $5 \pm 1{ }^{\circ} \mathrm{C}$ for 25 days & $\begin{array}{l}\text { Inhibitory effect against total } \\
\text { bacteria count, yeasts and } \\
\text { molds growth }\end{array}$ & Li et al. (2018) \\
\hline $\begin{array}{l}\text { Bergamot essential oils }+ \\
\mathrm{TiO}_{2}+\text { AgNPS }\end{array}$ & PLA & Mangoes & $\begin{array}{c}\text { Room temperature, } \\
15 \text { days }\end{array}$ & $\begin{array}{l}\text { Effectiveness against total } \\
\text { bacteria count }\end{array}$ & Chi et al. (2019) \\
\hline
\end{tabular}

PVC: Polyvinyl chloride; LDPE: Low density polyethylene; PLA: Poly lactic acid matrix; NI: Not informed. 
effect of nanocomposite packages of chicken breast containing different $\mathrm{ZnO}$ and $\mathrm{Ag}$ ratios. However, the authors observed that the meat sensory attributes were slightly affected by the package, with increased cereal odor and tenderness after 10 days of storage, although no differences were found in color and appearance of the product after 21 days of storage.

Fernández et al. (2010) stored fresh melon cuts in plastic films based on cellulose incorporated with spherical AgNP (5 and $35 \mathrm{~nm}$ diameters), and obtained low counts of yeasts, mesophilic and psychrophilic bacteria, when compared with the control films (without AgNP). Beigmohammadi et al. (2016) developed low density polyethylene (LDPE) package films incorporated with $\mathrm{Ag}$, copper oxide $(\mathrm{CuO})$, and zinc oxide $(\mathrm{ZnO})$, and found a reduction in coliform counts of ultra-filtered cheese stored at $4 \pm 0.5^{\circ} \mathrm{C}$ for 4 weeks.

Azlin-Hasim et al. (2015) studied the effect of the combination between LDPE film package with AgNPs and modified atmosphere in the shelf life of chicken breast fillets. Two films were developed with the incorporation of AgNPs in the polymer ( 0.5 and $1 \%$ polymer weight, w/w), and tested for their antimicrobial activity against several bacterial species. Compared with the control film (without AgNPs), bacterial growth in the nanocomposite Ag/LDPE film was significantly inhibited until day 6 (up to $22.5 \%$ reduction), which significantly increased the shelf life of the chicken breast fillet. Kuuliala et al. (2015) also developed LDPE package films containing AgNPs to protect fresh pork sirloin stored at $6^{\circ} \mathrm{C}$ for 28 days. The antimicrobial effect of the films against the bacteria associated with meat spoilage was determined, including Leuconostoc gelidum subsp. gasicomitatum (LMG 18811T), Lactobacillus sakei (23K), Lactococcus piscium (MKFS47), Carnobacterium divergens (DSMZ 20623T) and Hafnia alvei (DSM30163). In the in vitro study of the films, they were effective against L. piscium, B. thermosphacta, H. alvei, L. sakei and $C$. divergens. However, the AgNPs films did not affect the microbial growth in the packed samples of pork sirloin during storage, when compared with the control. This finding was attributed to the different dynamics in silver ion release on meat surfaces, or to the interaction between silver and amino acids.

\section{Toxicological aspects of silver nanoparticles}

In spite of all the advantages related to the use of AgNPs, one possible constraint in the use of nanoparticles in food packages is their migration to the food, leading to potential toxicity problems (Panea et al., 2014). Echegoyen \& Nerín (2013) assessed Ag migration in three types of containers available in the USA, including polypropylene plastic bags and polyolefin containers. Ag migration was tested using two simulated food conditions using ethanol $(50 \% \mathrm{v} / \mathrm{v})$ and acetic acid $(3 \% \mathrm{v} / \mathrm{v})$ at $40{ }^{\circ} \mathrm{C}$ for 10 days and $70{ }^{\circ} \mathrm{C}$ for $2 \mathrm{~h}$. The authors demonstrated the migration of Ag from the package to the liquid, which was greater in acetic acid at $40{ }^{\circ} \mathrm{C}$ for 10 days. However, total $\mathrm{Ag}$ migration was below the maximum migration limits determined by European regulations. Jokar \& Abdul Rahman (2014) assessed the $\mathrm{Ag}^{+}$migration in simulated food conditions (distilled water, $3 \%$ acetic acid, 10\% ethanol) and in apple juice stored at 4 and $40{ }^{\circ} \mathrm{C}$ for 30 days. The migrated AG from package to the acetic acid solution and apple juice was higher than in ethanol and distilled water, indicating that acidity promotes $\mathrm{Ag}^{+}$release by the polymers due to their dissolution.

Recent studies have investigated the effects of AgNPs in vivo and in vitro (Garcia et al., 2016). AgNPs may accumulate in several organs, including the liver, kidneys, testicles, and brain (Bagheri-Abassi et al., 2015; Garcia et al., 2016). Garcia et al. (2016) demonstated that the oral exposure of Sprague Dawley adult rats to subchornic doses of AgNPs led to an accumulation of Ag in differnt tissues at doses of 50, 100 and $200 \mathrm{mg} / \mathrm{kg} /$ day. Moreover, high doses of AgNPs can cause hepatotoxic (El Mahdy et al., 2015), neurotoxic (Bagheri-Abassi et al., 2015), and genotoxic effects (El Mahdy et al., 2015; Patlolla et al., 2015). However, the possibility of migration of such toxic levels from active packages to foods is very low, although possible toxicological effects of AGNPs levels in foods as a consequence of migration from packages have not been assessed so far.

Li et al. (2018) evaluated the migration of AgNPs of poly (lactic acid) (PLA) matrix impregnated with TiO2 + AgNPs in Yunnan cottage cheese. The authors observed that the Ag ions migration $(0.02 \mathrm{mg} / \mathrm{kg})$ into the food increased with storage time. However, the total Ag migration was lower than the maximum migration limits $(10 \mathrm{mg} / \mathrm{Kg})$ determined by European regulations for food contact material. Chi et al. (2018) studied the migration behavior of AgNPs from the PLA films in the presence of 50\% (v/v) ethanol as a food simulant. The author reported that high pressure treatment at 200 to $400 \mathrm{MPa}$ reduced the migration of AgNPs from the films. The amounts of AgNPs migrated were 0.354 and $0.409 \mathrm{mg} / \mathrm{Kkg}$ for treatment at 200 to $400 \mathrm{MPa}$, respectively. Thus, the author conclude that the PLA films treated by high pressure were safe and suitable for contact with foodstuffs.

\section{Conclusions}

Silver nanoparticles are potential antimicrobial agents against a wide range of microorganisms, including highly pathogenic Gram-positive and Gram-negative bacteria and fungi. Biological synthesis of AgNPs is considered the most correct and reliable method to obtain these particles. The use of bacteria and fungi has been widely explored for extracellular biosynthesis of AgNPs, demonstrating to be efficient and promising. Polymers are the main materials tested for impregnation with AgNPs to produce active food packages. However, it is important to carry out migration tests when a new package based on AgNP is produced. Additionally, further studies are necessary to determine the effective levels for AgNP inclusion in food packages.

\section{References}

AbdelRahim, K., Mahmoud, S. Y., Ali, A. M., Almaary, K. S., Mustafa, A. E. Z. M. A., \& Husseiny, S. M. (2017). Extracellular biosynthesis of silver nanoparticles using Rhizopus stolonifer. Saudi Journal of Biological Sciences, 24(1), 208-216. http://dx.doi.org/10.1016/j. sjbs.2016.02.025. PMid:28053592.

Almeida, A. C. S., Franco, A. E. N., Peixoto, F. M., Pessanha, K. L., \& Melo, N. R. (2015). Application of nanothecnology in food packaging. Polímeros, 25, 89-97. http://dx.doi.org/10.1590/0104-1428.2069.

Azlin-Hasim, S., Cruz-Romero, M. C., Morris, M. A., Cummins, E., \& Kerry, J. P. (2015). Effects of a combination of antimicrobial silver low density polyethylene nanocomposite films and modified atmosphere 
packaging on the shelf life of chicken breast fillets. Food Packaging and ShelfLife, 4, 26-35. http://dx.doi.org/10.1016/j.fpsl.2015.03.003.

Bagheri-Abassi, F., Alavi, H., Mohammadipour, A., Motejaded, F., \& Ebrahimzadeh-Bideskan, A. (2015). The effect of silver nanoparticles on apoptosis and dark neuron production in rat hippocampus. Iranian Journal of Basic Medical Sciences., 18(7), 644-648. PMid:26351553.

Balakumaran, M. D., Ramachandran, R., \& Kalaichelvan, P. T. (2015). Exploitation of endophytic fungus, Guignardia mangiferae for extracellular synthesis of silver nanoparticles and their in vitro biological activities. Microbiological Research, 178, 9-17. http:// dx.doi.org/10.1016/j.micres.2015.05.009. PMid:26302842.

Beigmohammadi, F., Peighambardoust, S. H., Hesari, J., AzadmardDamirchi, S., Peighambardoust, S. J., \& Khosrowshahi, N. K. (2016). Antibacterial properties of LDPE nanocomposite films in packaging of UF cheese. Lebensmittel-Wissenschaft + Technologie, 65, 106-111. http://dx.doi.org/10.1016/j.lwt.2015.07.059.

Berni, E. A. No., Ribeiro, C., \& Zucolotto, V. (2008). Síntese de nanopartículas de prata para aplicação na sanitização de embalagens (Comunicado Técnico, No. 99, 4 p.). São Carlos: EMBRAPA. Retrieved from http:// agris.fao.org/agris-search/search.do?recordID=BR2008131734

Buszewski, B., Railean-Plugaru, V., Pomastowski, P., Rafińska, K., Szultka-Mlynska, M., Golinska, P., Wypij, M., Laskowski, D., \& Dahm, H. (2018). Antimicrobial activity of biosilver nanoparticles produced by a novel Streptacidiphilus durhamensis strain. Journal of Microbiology, Immunology, and Infection, 51(1), 45-54. http:// dx.doi.org/10.1016/j.jmii.2016.03.002. PMid:27103501.

Carbone, M., Donia, D. T., Sabbatella, G., \& Antiochia, R. (2016). Silver nanoparticles in polymeric matrices for fresh food packaging. Journal of King Saud University - Science, 28(4), 273-279. https:// doi.org/10.1016/j.jksus.2016.05.004.

Chen, X., Yan, J. K., \& Wu, J. Y. (2016). Characterization and antibacterial activity of silver nanoparticles prepared with a fungal exopolysaccharide in water. Food Hydrocolloids, 53, 69-74. http://dx.doi.org/10.1016/j. foodhyd.2014.12.032.

Chi, H., Song, S., Luo, M., Zhang, C., Li, W., Li, L., \& Qin, Y. (2019). Effect of PLA nanocomposite films containing bergamot essential oil, $\mathrm{TiO}_{2}$ nanoparticles, and $\mathrm{Ag}$ nanoparticles on shelf life of mangoes. Scientia Horticulturae, 249, 192-198. http://dx.doi.org/10.1016/j. scienta.2019.01.059.

Chi, H., Xue, J., Zhang, C., Chen, H., Li, L., \& Qin, Y. (2018). High pressure treatment for improving water vapour barrier properties of poly (lactic acid)/Ag nanocomposite films. Polymers, 10(9), 1-11. http://dx.doi.org/10.3390/polym10091011. PMid:30960936.

Claro, F. C., \& Magalhães, W. L. E. (2017). Síntese de nanopartículas de prata em filmes de nanocelulose. Embrapa, 149, 149-152.

Das, L. V., Thomas, R., Varghese, R. T., Soniya, E. V., Mathew, J., \& Radhakrishnan, E. K. (2014). Extracellular synthesis of silver nanoparticles by the Bacillus strain CS 11 isolated from industrialized area. 3 Biotech, 4(2), 121-126. https://doi.org/10.1007/s13205-0130130-8.

Devi, L. S., \& Joshi, S. R. (2014). Evaluation of the antimicrobial potency of silver nanoparticles biosynthesized by using an endophytic fungus, Cryptosporiopsis ericae PS4. Journal of Microbiology (Seoul, Korea), 52(8), 667-674. http://dx.doi.org/10.1007/s12275-014-4113-1. PMid:24994011.

Devi, L. S., \& Joshi, S. R. (2015). Ultrastructures of silver nanoparticles biosynthesized using endophytic fungi. Journal of Microscopy and Ultrastructure, 3(1), 29-37. http://dx.doi.org/10.1016/j.jmau.2014.10.004. PMid:30023179.
Durán, N., Marcato, P. D., Conti, R. D., Alves, O. L., Costa, F. T. M., \& Brocchi, M. (2010). Potential use of silver nanoparticles on pathogenic bacteria, their toxicity and possible mechanisms of action. Journal of the Brazilian Chemical Society, 21(6), 949-959. http://dx.doi. org/10.1590/S0103-50532010000600002.

Echegoyen, Y., \& Nerín, C. (2013). Nanoparticle release from nano-silver antimicrobial food containers. Food and Chemical Toxicology, 62, 16-22. http://dx.doi.org/10.1016/j.fct.2013.08.014. PMid:23954768.

El Mahdy, M. M., Eldin, T. A. S., Aly, H. S., Mohammed, F. F., \& Shaalan, M. I. (2015). Evaluation of hepatotoxic and genotoxic potential of silver nanoparticles in albino rats. Experimental and Toxicologic Pathology, 67(1), 21-29. http://dx.doi.org/10.1016/j.etp.2014.09.005. PMid:25446800.

Elbeshehy, E. K. F., Elazzazy, A. M., \& Aggelis, G. (2015). Silver nanoparticles synthesis mediated by new isolates of Bacillus spp., nanoparticle characterization and their activity against Bean Yellow Mosaic Virus and human pathogens. Frontiers in Microbiology, 6, 1-13. http://dx.doi.org/10.3389/fmicb.2015.00453. PMid:26029190.

Emamifar, A., Kadivar, M., Shahedi, M., \& Solimanian-Zad, S. (2012). Effect of nanocomposite packaging containing $\mathrm{Ag}$ and $\mathrm{ZnO}$ on reducing pasteurization temperature of orange juice. Journal of Food Processing and Preservation, 36(2), 104-112. http://dx.doi. org/10.1111/j.1745-4549.2011.00558.x.

Fernández, A., Picouet, P., \& Lloret, E. (2010). Cellulose-silver nanoparticle hybrid materials to control spoilage-related microflora in absorbent pads located in trays of fresh-cut melon. International Journal of Food Microbiology, 142(1-2), 222-228. http://dx.doi.org/10.1016/j. ijfoodmicro.2010.07.001. PMid:20656367.

Gade, A., Gaikwad, S., Duran, N., \& Rai, M. (2013). Screening of different species of Phoma for the synthesis of silver nanoparticles. Biotechnology and Applied Biochemistry, 60(5), 482-493. http:// dx.doi.org/10.1002/bab.1141. PMid:23848561.

Gallocchio, F., Cibin, V., Biancotto, G., Roccato, A., Muzzolon, O., Carmen, L., Simone, B., Manodori, L., Fabrizi, A., Patuzzi, I., \& Ricci, A. (2016). Testing nano-silver food packaging to evaluate silver migration and food spoilage bacteria on chicken meat. Food Additives and Contaminants - Part A, 33(6), 1063-1071. http://dx.doi. org/10.1080/19440049.2016.1179794. PMid:27147130.

Garcia, T., Lafuente, D., Blanco, J., Sánchez, D. J., Sirvent, J. J., Domingo, J. L., \& Gómez, M. (2016). Oral subchronic exposure to silver nanoparticles in rats. Food and Chemical Toxicology, 92, 177-187. http://dx.doi.org/10.1016/j.fct.2016.04.010. PMid:27090107.

Gopinath, V., \& Velusamy, P. (2013). Extracellular biosynthesis of silver nanoparticles using Bacillus sp. GP-23 and evaluation of their antifungal activity towards Fusarium oxysporum. Spectrochimica Acta. Part A: Molecular and Biomolecular Spectroscopy, 106, 170174. http://dx.doi.org/10.1016/j.saa.2012.12.087. PMid:23376272.

Gopinath, V., Priyadarshini, S., Loke, M. F., Arunkumar, J., Marsili, E., MubarakAli, D., Velusamy, P., \& Vadivelu, J. (2017). Biogenic synthesis, characterization of antibacterial silver nanoparticles and its cell cytotoxicity. Arabian Journal of Chemistry, 10(8), 1107-1117. http://dx.doi.org/10.1016/j.arabjc.2015.11.011.

Gudikandula, K., Vadapally, P., \& Singara Charya, M. A. (2017). OpenNano biogenic synthesis of silver nanoparticles from white rot fungi: their characterization and antibacterial studies. OpenNano, 2, 64-78. http://dx.doi.org/10.1016/j.onano.2017.07.002.

Hamedi, S., Ghaseminezhad, M., Shokrollahzadeh, S., \& Shojaosadati, S. A. (2017). Controlled biosynthesis of silver nanoparticles using nitrate reductase enzyme induction of filamentous fungus and their antibacterial evaluation. Artificial Cells, Nanomedicine, and 
Biotechnology, 45(8), 1588-1596. http://dx.doi.org/10.1080/21691 401.2016.1267011. PMid:27966375.

Husseiny, S. M., Salah, T. A., \& Anter, H. A. (2015). Biosynthesis of size controlled silver nanoparticles by Fusarium oxysporum, their antibacterial and antitumor activities. Beni-Suef University Journal of Basic and Applied Sciences, 4(3), 225-231. http://dx.doi.org/10.1016/j. bjbas.2015.07.004.

Jokar, M., \& Abdul Rahman, R. (2014). Study of silver ion migration from melt-blended and layered-deposited silver polyethylene nanocomposite into food simulants and apple juice. Food Additives \& Contaminants. Part A, Chemistry, Analysis, Control, Exposure \& Risk Assessment, 31(4), 734-742. http://dx.doi.org/10.1080/194400 49.2013.878812. PMid:24392748.

Kanmani, P., \& Lim, S. T. (2013). Synthesis and structural characterization of silver nanoparticles using bacterial exopolysaccharide and its antimicrobial activity against food and multidrug resistant pathogens. Process Biochemistry, 48(7), 1099-1106. http://dx.doi.org/10.1016/j. procbio.2013.05.011.

Kuuliala, L., Pippuri, T., Hultman, J., Auvinen, S. M., Kolppo, K., Nieminen, T., Karp, M., Björkroth, J., Kuusipalo, J., \& Jääskeläinen, E. (2015). Preparation and antimicrobial characterization of silvercontaining packaging materials for meat. Food Packaging and Shelf Life, 6, 53-60. http://dx.doi.org/10.1016/j.fpsl.2015.09.004.

Li, W., Li, L., Zhang, H., Yuan, M., \& Qin, Y. (2018). Evaluation of PLA nanocomposite films on physicochemical and microbiological properties of refrigerated cottage cheese. Journal of Food Processing and Preservation, 42(1), 1-9. http://dx.doi.org/10.1111/jfpp.13362.

Ma, L., Su, W., Liu, J. X., Zeng, X. X., Huang, Z., Li, W., Liu, Z. C., \& Tang, J. X. (2017). Optimization for extracellular biosynthesis of silver nanoparticles by Penicillium aculeatum Sul and their antimicrobial activity and cytotoxic effect compared with silver ions. Materials Science and Engineering C, 77, 963-971. http://dx.doi.org/10.1016/j. msec.2017.03.294. PMid:28532117.

Madakka, M., Jayaraju, N., \& Rajesh, N. (2018). Mycosynthesis of silver nanoparticles and their characterization. MethodsX, 5, 20-29. http:// dx.doi.org/10.1016/j.mex.2017.12.003. PMid:30619720.

Mahdi, S. S., Vadood, R., \& Nourdahr, R. (2012). Study on the antimicrobial effect of nanosilver tray packaging of minced beef at refrigerator temperature. Global Veterinaria, 9(3), 284-289. http:// dx.doi.org/10.5829/idosi.gv.2012.9.3.1827.

Manikprabhu, D., \& Lingappa, K. (2013). Antibacterial activity of silver nanoparticles against methicillin-resistant staphylococcus aureus synthesized using model streptomyces sp. pigment by photoirradiation method. Journal of Pharmacy Research, 6(2), 255-260. http://dx.doi.org/10.1016/j.jopr.2013.01.022.

Manivasagan, P., Venkatesan, J., Senthilkumar, K., Sivakumar, K., \& Kim, S. K. (2013). Biosynthesis, antimicrobial and cytotoxic effect of silver nanoparticles using a novel Nocardiopsis sp. MBRC1. BioMed Research International, 2013, 287638. http://dx.doi. org/10.1155/2013/287638. PMid:23936787.

Martinez-Abad, A., Lagaron, J. M., \& Ocio, M. J. (2012). Development and characterization of silver-based antimicrobial ethylene-vinyl alcohol copolymer (EVOH) films for food-packaging applications. Journal of Agricultural and Food Chemistry, 60(21), 5350-5359. http://dx.doi.org/10.1021/jf300334z. PMid:22577863.

Mohanta, Y. K., \& Behera, S. K. (2014). Biosynthesis, characterization and antimicrobial activity of silver nanoparticles by Streptomyces sp. SS2. Bioprocess and Biosystems Engineering, 37(11), 2263-2269. http://dx.doi.org/10.1007/s00449-014-1205-6. PMid:24842223.

Morones, J. R., Elechiguerra, J. L., Camacho, A., Holt, K., Kouri, J. B., Ramírez, J. T., \& Yacaman, M. J. (2005). The bactericidal effect of silver nanoparticles. Nanotechnology, 16(10), 2346-2353. http:// dx.doi.org/10.1088/0957-4484/16/10/059. PMid:20818017.

Morsy, M. K., Khalaf, H. H., Sharoba, A. M., El-Tanahi, H. H., \& Cutter, C. N. (2014). Incorporation of Essential Oils and Nanoparticles in Pullulan Films to Control Foodborne Pathogens on Meat and Poultry Products. Journal of Food Science, 79(4), M675-M684. http://dx.doi. org/10.1111/1750-3841.12400. PMid:24621108.

Neethu, S., Midhun, S. J., Radhakrishnan, E. K., \& Jyothis, M. (2018). Green synthesized silver nanoparticles by marine endophytic fungus Penicillium polonicum and its antibacterial efficacy against biofilm forming, multidrug-resistant Acinetobacter baumanii. Microbial Pathogenesis, 116, 263-272. http://dx.doi.org/10.1016/j. micpath.2018.01.033. PMid:29366864.

Neihaya, H. Z., \& Zaman, H. H. (2018). Investigating the effect of biosynthesized silver nanoparticles as antibiofilm on bacterial clinical isolates. Microbial Pathogenesis, 116, 200-208. http://dx.doi. org/10.1016/j.micpath.2018.01.024. PMid:29414608.

Ninganagouda, S., Rathod, V., Jyoti, H., Singh, D., Prema, K., \& ManzoorUl-Haq, S. (2013). Aspergillus flavus and their antimicrobial activity. International Journal of Pharma and Bio Sciences, 4(2), 222-229. Retrieved from https://www.researchgate.net/publication/236943 633\%0AEXTRACELLULAR

Oves, M., Khan, M. S., Zaidi, A., Ahmed, A. S., Ahmed, F., Ahmad, E., Sherwani, A., Owais, M., \& Azam, A. (2013). Antibacterial and cytotoxic efficacy of extracellular silver nanoparticles biofabricated from chromium reducing Novel OS4 Strain of Stenotrophomonas maltophilia. PLoS One, 8(3), e59140. http://dx.doi.org/10.1371/ journal.pone.0059140. PMid:23555625.

Pal, S., Tak, Y. K., \& Song, J. M. (2007). Does the antibacterial activity of silver nanoparticles depend on the shape of the nanoparticle? A study of the gram-negative bacterium Escherichia coli. The Journal of Biological Chemistry, 73(6), 1712-1720. http://dx.doi.org/10.1128/ AEM.02218-06. PMid:17261510.

Panea, B., Ripoll, G., González, J., Fernández-Cuello, Á., \& Albertí, P. (2014). Effect of nanocomposite packaging containing different proportions of $\mathrm{ZnO}$ and $\mathrm{Ag}$ on chicken breast meat quality. Journal of Food Engineering, 123, 104-112. http://dx.doi.org/10.1016/j. jfoodeng.2013.09.029.

Patlolla, A. K., Hackett, D., \& Tchounwou, P. B. (2015). Genotoxicity study of silver nanoparticles in bone marrow cells of SpragueDawley rats. Food and Chemical Toxicology, 85, 52-60. http://dx.doi. org/10.1016/j.fct.2015.05.005. PMid:26032631.

Peiris, M. K., Gunasekara, C. P., Jayaweera, P. M., Arachchi, N. D. H., \& Fernando, N. (2017). Biosynthesized silver nanoparticles: Are they effective antimicrobials? Memorias do Instituto Oswaldo Cruz, 112(8), 537-543. http://dx.doi.org/10.1590/0074-02760170023. PMid:28767978.

Prakasham, R. S., Buddana, S. K., Yannam, S. K., \& Guntuku, G. S. (2012). Characterization of silver nanoparticles synthesized by using marine isolate Streptomyces albidoflavus. Journal of Microbiology and Biotechnology, 22(5), 614-621. http://dx.doi.org/10.4014/ jmb.1107.07013. PMid:22561854.

Prakasham, R. S., Kumar, B. S., Kumar, Y. S., \& Kumar, K. P. (2014). Production and Characterization of Protein Encapsulated Silver Nanoparticles by Marine Isolate Streptomyces parvulus SSNP11. Indian Journal of Microbiology, 54(3), 329-336. http://dx.doi. org/10.1007/s12088-014-0452-1. PMid:24891741.

Qian, Y., Yu, H., He, D., Yang, H., Wang, W., Wan, X., \& Wang, L. (2013). Biosynthesis of silver nanoparticles by the endophytic fungus Epicoccum nigrum and their activity against pathogenic 
fungi. Bioprocess and Biosystems Engineering, 36(11), 1613-1619. http://dx.doi.org/10.1007/s00449-013-0937-z. PMid:23463299.

Saravanan, M., Arokiyaraj, S., Lakshmi, T., \& Pugazhendhi, A. (2018). Microbial pathogenesis synthesis of silver nanoparticles from Phenerochaete chrysosporium (MTCC- 787) and their antibacterial activity against human pathogenic bacteria. Microbial Pathogenesis, 117, 68-72. http://dx.doi.org/10.1016/j.micpath.2018.02.008. PMid:29427709.

Silvestre, C., Duraccio, D., \& Cimmino, S. (2011). Food packaging based on polymer nanomaterials. Progress in Polymer Science, 36(12), 1766-1782. http://dx.doi.org/10.1016/j.progpolymsci.2011.02.003.

Singh, D., Rathod, V., Ninganagouda, S., Herimath, J., \& Kulkarni, P. (2013a). Biosynthesis of silver nanoparticle by endophytic fungi Pencillium sp. isolated from Curcuma longa (turmeric) and its antibacterial activity against pathogenic gram negative bacteria. Journal of Pharmacy Research, 7(5), 448-453. http://dx.doi.org/10.1016/j.jopr.2013.06.003.

Singh, R., Wagh, P., Wadhwani, S., Gaidhani, S., Kumbhar, A., Bellare, J., \& Chopade, B. A. (2013b). Synthesis, optimization, and characterization of silver nanoparticles from Acinetobacter calcoaceticus and their enhanced antibacterial activity when combined with antibiotics. International Journal of Nanomedicine, 8, 4277-4290. http://dx.doi. org/10.2147/IJN.S48913. PMid:24235826.

Singh, H., Du, J., Singh, P., \& Hoo, T. (2018). Extracellular synthesis of silver nanoparticles by Pseudomonas sp. THG-LS1.4 and their antimicrobial application. Journal of Pharmaceutical Analysis, 8(4), 258-264. https://doi.org/10.1016/j.jpha.2018.04.004.

Singh, T., Jyoti, K., Patnaik, A., Singh, A., Chauhan, R., \& Chandel, S. (2017). Biosynthesis, characterization and antibacterial activity of silver nanoparticles using an endophytic fungal supernatant of Raphanus sativus. Journal of Genetic Engineering and Biotechnology, 15(1), 3139. http://dx.doi.org/10.1016/j.jgeb.2017.04.005. PMid:30647639.

Sobye, A., Kolding, A., Jorgensen, J. K., Lund, M. K., \& Mikkelsen, M. O. (2015). Bactericidal effect of silver nanoparticles: determination of size and shape of triangular silver nanoprisms and spherical silver nanoparticles and their bactericidal effect against Escherichia coli and Bacillus subtilis (pp. 9-76). Aalborg: School of Engineering and Science Nanotechnology.

Sogra Fathima, B., \& Balakrishnan, R. M. (2014). Biosynthesis and optimization of silver nanoparticles by endophytic fungus Fusarium solani. Materials Letters, 132, 428-431. http://dx.doi.org/10.1016/j. matlet.2014.06.143.

Srivastava, S., Bhargava, A., Pathak, N., \& Srivastava, P. (2019). Production, characterization and antibacterial activity of silver nanoparticles produced by Fusarium oxysporum and monitoring of protein- ligand interaction through in-silico approaches. Microbial Pathogenesis, 129, 136-145. http://dx.doi.org/10.1016/j.micpath.2019.02.013. PMid:30742948.

Tavakoli, H., Rastegar, H., Taherian, M., Samadi, M., \& Rostami, H. (2017). The effect of nano silver packaging in increasing the shelf life of nuts: an in vitro model. Italian Journal of Food Safety, 6(4), 6874. http://dx.doi.org/10.4081/ijfs.2017.6874. PMid:29564232.

Wei, X., Luo, M., Li, W., Yang, L., Liang, X., Xu, L., Kong, P., \& Liu, H. (2012). Synthesis of silver nanoparticles by solar irradiation of cell-free Bacillus amyloliquefaciens extracts and AgNO3. Bioresource Technology, 103(1), 273-278. http://dx.doi.org/10.1016/j.biortech.2011.09.118. PMid:22019398.

Wypij, M., Swiecimska, M., Czarnecka, J., Dahm, H., Rai, M., \& Golinska, P. (2018). Antimicrobial and cytotoxic activity of silver nanoparticles synthesized from two haloalkaliphilic actinobacterial strains alone and in combination with antibiotics. Journal of Applied Microbiology, 124(6), 1411-1424. http://dx.doi.org/10.1111/jam.13723. PMid:29427473.

Yurtluk, T., Akçay, F. A., \& Avci, A. (2018). Biosynthesis of silver nanoparticles using novel Bacillus sp. SBT8. Preparative Biochemistry \& Biotechnology, 48(2), 151-159. http://dx.doi.org/10.1080/108260 68.2017.1421963. PMid:29313428. 